\title{
Studies on Growth of Fusarium oxysporum f. sp. vasinfectum Isolates causing Okra Wilt on Different Culture Media
}

\author{
B. Hanumanthe Gowda ${ }^{1 *}$, Somashekher ${ }^{1}$ and M. Saifulla ${ }^{2}$ \\ ${ }^{1}$ Krishi Vigyan Kendra (IIHR), Hirehalli, Tumkuru Distrct-571168, India \\ ${ }^{2}$ Department of Plant Pathology, UAS, GKVK, Bengaluru-65, India \\ *Corresponding author
}

\section{A B S T R A C T}

\begin{tabular}{l} 
K e y w o r d s \\
$\begin{array}{l}\text { Fusarium } \\
\text { oxysporum f. sp. } \\
\text { vasinfectum, } \\
\text { Culture media, } \\
\text { Okra, Colony } \\
\text { growth }\end{array}$ \\
\hline $\begin{array}{l}\text { Article Info } \\
\text { Accepted: } \\
\text { 12 August } 2020 \\
\text { Available Online: } \\
\text { 10 September } 2020\end{array}$ \\
\hline
\end{tabular}

\begin{abstract}
The present study was undertaken to find out the suitability of culture media for growth of twenty five isolates of Fusarium oxysporum f. sp. vasinfectum collected and isolated from different locations of Karnataka state using Czapek's dox agar (CDA), Potato dextrose agar (PDA), Richards Agar (RA) and Yeast Extract Agar (YEA). Significant variation recorded among twenty five isolates with respect to growth i.e colony diameter on different solid media. Isolates MYS-15 and MYS-16 showed fastest growth of $65.49 \mathrm{~mm}$ and $64.38 \mathrm{~mm}$ respectively after seven days in all the media tested. Richard's agar found to be the best for the growth of all the isolates tested with mean colony diameter of 61.78 $\mathrm{mm}$. Twenty three isolates were exhibited fast colony growth and only two isolates were exhibited very fast colony growth. In liquid media, the growth of all the isolates was very good in Richard's medium with mean dry mycelial weight of $526.33 \mathrm{mg}$, whereas Yeast extract liquid media supported poorly for the growth of most of the isolates with mean dry mycelial weight of $321.27 \mathrm{mg}$. Twenty four isolates were categorized as fast growers with mean dry mycelial weight ranging from 300.1-450 mg and only one isolate (MYS-15) was exhibited very fast colony growth with mean dry mycelial weight of $451.18 \mathrm{mg}$.
\end{abstract}

\section{Introduction}

Okra (Abelmoschusesculentus L. (Moench)), is an economically important vegetable crop grown in tropical and sub-tropical parts of the world. This crop is suitable for cultivation as a garden crop as well as on large commercial farms. Fusarium oxysporum f. sp. vasinfectum is one of the important pathogen reported to cause destructive disease like wilt.(Sultana et al., 1988). F. oxysporum is cosmopolitan in distribution and considered as one of the most important soil-borne fungi present in wide range of soils can infect root system and consequently invade the vascular tissues of the plants (Olivain and Alabouvette, 1997). The disease has been responsible for significant yield loss in all okra growing areas (Silva et al., 2007a). Rough estimates indicated that Fusarium wilt causes loss around 10-15 per cent each year as regular feature. In the years of severe epidemics, crop losses will go as high as 60-70 per cent (Jalali and Harichand, 1992). 
Variation in the type of carbon and nitrogen sources besides changes in $\mathrm{pH}$, temperature, incubation period, have great influence on the growth of pathogen. Present work depicts the role of different media to growth of the pathogen which will be helpful in management strategy in the field.

\section{Materials and Methods}

\section{Solid medium}

The growth of the $F$. oxysporum f. sp. vasinfectum were studied on solid media viz., Czapek's dox agar, Richard's agar, Potato dextrose agar, and Yeast extract agar. Twenty $\mathrm{ml}$ of each medium listed above was poured into $90 \mathrm{~mm}$ diameter petriplates. After solidification, $5 \mathrm{~mm}$ discs of $F$. oxysporum $\mathrm{f}$. sp. vasinfectum from actively growing culture were cut using a cork borer and a single disc was placed upside down at the centre of petridish. Each set of experiment was replicated thrice and the plates were incubated at $28 \pm 1^{\circ} \mathrm{C}$ for 7 days. Based on the mean colony growth on different solid medium, isolates were categorized into four groups (Anon. 2006) viz., I- Slow (<30 colony diameter), II-Medium (<30.1-45colony diameter), III-Fast (45.1-60 colony diameter), and IV-Very fast (60mm colony diameter).

\section{Liquid Medium}

The cultural characters of 25 isolates were studied on four liquid media viz., Czapek's dox solution, Richard's broth, Potato dextrose broth, Yeast extract broth. $100 \mathrm{ml}$ of all respective broth were poured into $250 \mathrm{ml}$ conical flask and sterilized. Seven day old five $\mathrm{mm}$ mycelial disc of the pathogen was inoculated separately into the conical flasks. Each treatment was replicated thrice and incubated at $28 \pm 1^{\circ} \mathrm{C}$ for 7 days. Cultures were filtered through whatman's No.1 filter paper washed thoroughly with distilled water.
It was dried at $40^{\circ} \mathrm{C}$ for two days in hot air oven and weight was recorded. Based on the mean mycelial weight, isolates were classified into following four groups viz., Slow $(<150$ $\mathrm{mg}$ ), Medium (150.1-300 mg), Fast (300.1$450 \mathrm{mg}$ ) and Very fast (450.1-600 mg).

\section{Results and Discussion}

\section{Growth on solid media}

There was a significant variation recorded among twenty five isolates with respect to growth on different solid media and also in terms of colony diameter $(\mathrm{mm})$ as shown in the Fig. 1. Similarly, there was marked difference among the media with each of the isolates. Results on interaction effect between media and the isolates were also found to be significant. It was found that, isolates MYS15 and MYS-16 showed fastest growth of $65.49 \mathrm{~mm}$ and $64.38 \mathrm{~mm}$ respectively after seven days in all the media tested. Richard's agar found to be the best for the growth of all the isolates tested with mean colony diameter of $61.78 \mathrm{~mm}$, which was statistically significant over all other media tested (Fig. 1).

On the basis of radial growth isolates were classified. Twenty three isolates were exhibited fast colony growth and only two isolates viz., MYS-15 and MYS-16were exhibited very fast colony growth. It was very interesting to note that none of the isolates were recorded under slow and medium colony growth groups (Table 1).

\section{Growth on liquid media}

Results in the Fig. 2 indicates that the growth of all the isolates was very good in Richard's medium with mean dry mycelial weight of $526.33 \mathrm{mg}$, whereas Yeast extract liquid media supported poorly for the growth of most of the isolates with mean dry mycelial weight of $321.27 \mathrm{mg}$. Among the twenty five 
isolates studies, two isolates viz., MYS-15 and MYS-16 recorded maximum dry mycelial weight in Richard's medium with $451.18 \mathrm{mg}$ and $444.54 \mathrm{mg}$, respectively. Richard's medium found to be the best for the growth of all the isolates tested with mean dry mycelial weight of $526.33 \mathrm{mg}$, which was statistically significant over all other media tested. The Czapeck's and Potato dextrose liquid media supported the growth of all the $25 F$. oxysporum f. sp. vasinfectum isolates with mean dry mycelial weight of $354.24 \mathrm{mg}$ and $353.29 \mathrm{mg}$, respectively and both were found at par. However, Yeast extract agar medium recorded poorest growth of all the tested isolates with mean dry mycelial weight of $321.27 \mathrm{mg}$.

None of the isolates fell under group-I (Slow growers) and group II as shown in the Table 2. Twenty four isolates were categorized under group-III (Fast growers) with mean dry mycelial weight ranging from 300.1-450 mg and only one isolate (MYS-15) was exhibited very fast colony growth with mean dry mycelial weight of $451.18 \mathrm{mg}$.

Table.1 Classification of $F$. oxysporum f.sp. vasinfectum isolates based on colony growth on different solid media

\begin{tabular}{|c|c|c|c|l|}
\hline Group & Growth & $\begin{array}{c}\text { Mean colony } \\
\text { diameter }(\mathbf{m m})\end{array}$ & $\begin{array}{c}\text { No. of } \\
\text { isolates }\end{array}$ & \multicolumn{1}{|c|}{ Name of the isolates } \\
\hline I & Slow & $<30$ & 0 & - \\
\hline II & Medium & $30.1-45$ & 0 & \\
\hline III & Fast & $45.1-60$ & 23 & $\begin{array}{l}\text { CRNR-19, HSN-21, CBP-24, TMK-5, TMK- } \\
\end{array}$ \\
& & & $\begin{array}{l}\text { 6, RMNR-8, MDY-11, MDY-13, MYS-17, } \\
\text { CRNR-18, HSN-20, CHD-22, CBP- }\end{array}$ \\
& & & $\begin{array}{l}\text { 25BNGU-1, BNGU-2, TMK-4, TMK-7, } \\
\text { MDY-14, CHD-23, BNGR-3, RMNR-9, }\end{array}$ \\
& & & & RMNR-10 and MDY-12 \\
\hline IV & Very fast & $>60$ & 02 & MYS-15 and MYS-16, \\
\hline
\end{tabular}

Table.2 Classification of $F$. oxysporum f. sp. vasinfectum isolates based on mycelial weight on different Liquid media

\begin{tabular}{|c|c|c|c|c|}
\hline Groups & Growth rate & Dry mycelial weight & $\begin{array}{l}\text { No. of } \\
\text { isolates }\end{array}$ & Name of the isolates \\
\hline I- & Slow & $<150 \mathrm{mg}$ & - & - \\
\hline II & Medium & $150.1-300 \mathrm{mg}$ & - & - \\
\hline III & Fast & $300.1-450 \mathrm{mg}$ & 24 & $\begin{array}{l}\text { BNGU-1, BNGU-2, BNGU-3, TMK-4, } \\
\text { TMK-5, TMK-6, TMK-7, RMNR-8, } \\
\text { RMNR-9, RMNR-10, MDY-11, MDY-12, } \\
\text { MDY-13, MDY-14, MYS-16,MYS-17, } \\
\text { CRNR-18, CRNR-19, HSN-20, HSN-21, } \\
\text { CHD-22, CHD-23,CBP-24, CBP-25 }\end{array}$ \\
\hline IV & Very fast & $450.1-600 \mathrm{mg}$ & 01 & MYS-15 \\
\hline
\end{tabular}



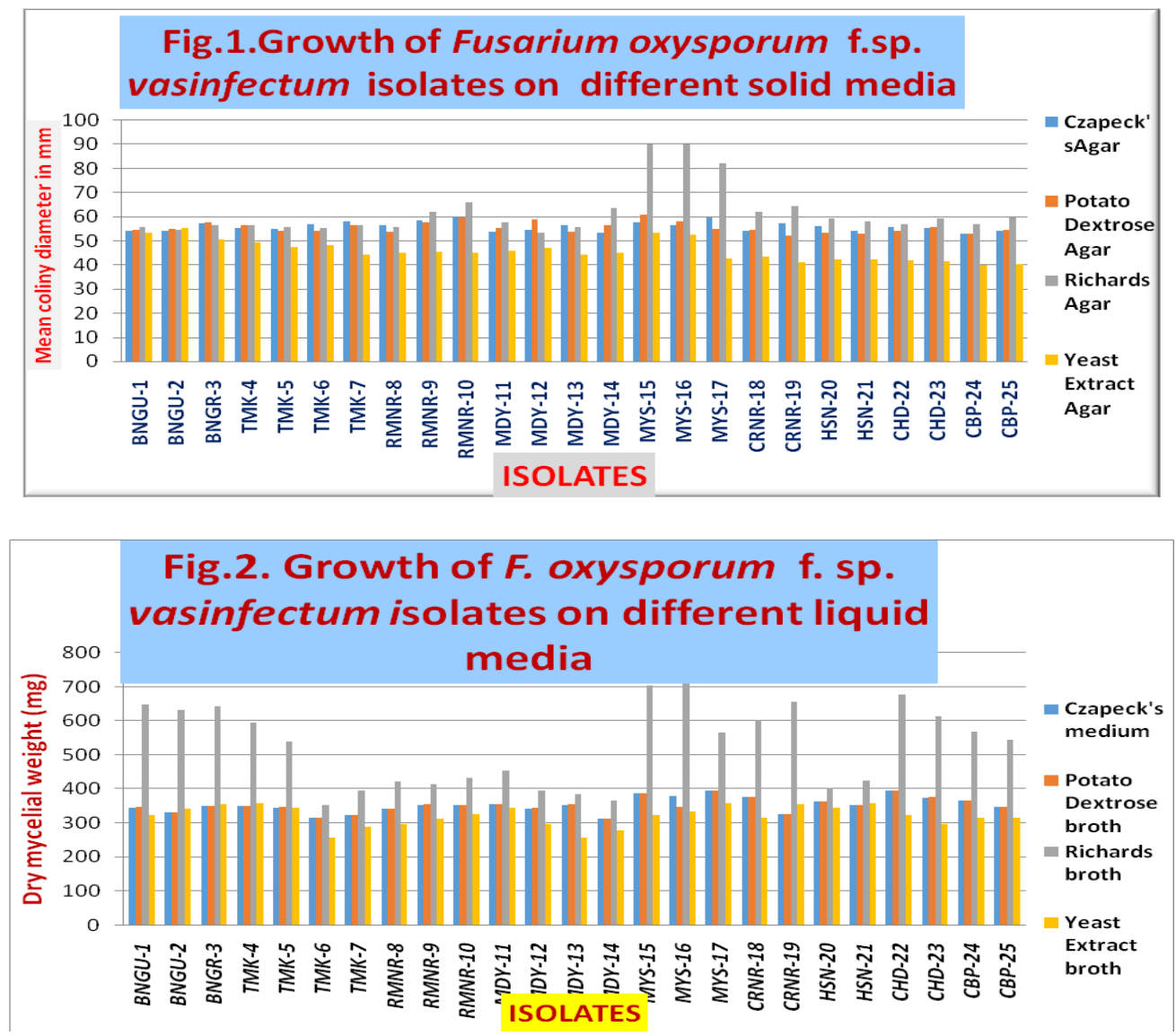

Nutrients are fundamental requirements of microorganisms for growth and development. Nutrient utilization and conversion of these into biomass was studied with respect to all twenty five isolates of $F$. oxysporum $\mathrm{f}$. sp. vasinfectum. The isolates exhibited significant variation in respect of their ability to grow on various media which indicated the existence of variability among the isolates. The present study also indicated that Richard's agar was the best source of among four media used for the growth and development of $F$. oxysporum f. sp. vasinfectum isolates both in solid (61.78mm mean colony diameter) and liquid media (526.33 mg mean dry mycelial weight). These results were in confirmation with Ingole (1995) who reported that PDA and Richard's agar supported best mycelial growth of Fusarium udum. Jamaria (1972) also reported maximum growth and sporulation of Fusarium oxysporum f.sp. vanillae on Potato dextrose agar, Richard's agar and Czapek's Dox agar. Khilareet al., (1975) reported maximum growth of Fusarium oxysporum f. sp. lentis on PDA followed by lentil extract and Richard's agar.These results were also similar with the findings of Major (1923) and Eshwarareddy and Basu choudary (1985), who studied the growth of $F$. udum in different liquid media and found that Richard's medium was the best medium for the growth of the fungus followed by Czapeck's medium. Anjaneya Reddy also observed maximum growth of $F$. udum on Richard's medium. Similarly, Mahesh (2004) and Mahesh (2008) also observed the maximum growth of $F$. udum on Richard's medium.

The isolates were categorized into four groups based on the colony diameter on solid media and mycelial weight in liquid media. These results were confirmed with Eshwarareddy and Basu Choudhary (1985), who grouped six 
isolates of $F$. udum into three distinct groups based on radial growth and colony characters. Gupta et al., (1988) also grouped seven different strains of $F$. udum on the basis of growth rate.

\section{Acknowledgement}

Authors are greatly acknowledged to the Director, IIHR for providing the facilities for conducting the study at CHES, Hirehalli.

\section{References}

Eshwara Reddy, N. P. and Basuchoudhary, K. C., 1985, Variation in Fusarium udum. Indian Phytopathol., 38: 172-173.

Gupta, O.M., Kotasthane, S.R. and Khare, M.N. (1988). Strain variation in Fusarium udum in Madhya Pradesh, India. International Pigeon pea Newsletter 7: 22-25.

Ingole, M. N., 1995, Estimation of losses, variability among isolates and management of pigeon pea wilt caused by Fusarium udum Butler. M.Sc. (Ag.) Thesis, PDKV, Akola, pp. 146.

Jamaria, S.L., 1972, Nutritional requirement of Fusarium oxysporum f.sp. niveum. Indian. Phytopatho., 25: 29- 32.

Khilare, V. C. and Rafi Ahmed, 2012, Effect of different media, $\mathrm{pH}$ and temperature on the growth of Fusarium oxysporum f. sp. ciceri causing chickpea wilt. Int. J. Adv. Biol. Res., 2(1): 99-102.

Major, J, G., 1923, Cultural characteristics of certain species of Fusarium. Fifteenth annual report. Quebec society of protection of plants, 33:79-87.

Mahesh, M., 2004, Investigation on Pigeon pea wilt caused by Fusarium udum Butler. M.Sc. thesis, Univ. Agri. Sci., Bangalore, $130 \mathrm{pp}$.

Mahesh, M., 2008, Variability and management of Pigeon pea wilt caused by Fusarium udum Butler. Ph.D. thesis, Univ. Agri. Sci., Bangalore, pp.189

\section{How to cite this article:}

Hanumanthe Gowda, B., Somashekher and Saifulla, M. 2020. Studies on Growth of Fusarium oxysporum f. sp. vasinfectum Isolates causing Okra Wilt on Different Culture Media. Int.J.Curr.Microbiol.App.Sci. 9(09): 1419-1423. doi: https://doi.org/10.20546/ijcmas.2020.909.179 